\title{
PENGARUH PERSEPSI KONSUMEN TERHADAP ATRIBUT PRODUK PADA SIKAP TERHADAP PRODUK DAN NIAT PEMBELIAN ULANG : Studi Empirik Pengambilan Keputusan pada Kategori Produk Daging Olahan Beku
}

\author{
THE EFFECT OF CONSUMER PERCEPTION ON PRODUCT ATTRIBUTES TO ATTITUDE \\ TOWARD PRODUCT AND REPEAT PURCHASE INTENTION : Empirical Study on Decision Making \\ of Frozen Processed Meat Product
}

\author{
Antofany Yusticia Ahmadi, Suci Paramitasari Syahlani*, dan F. Trisakti Haryadi \\ Fakultas Peternakan, Universitas Gadjah Mada, Jl. Fauna No.3, Bulaksmumur, Yogyakarta, 55281
}

\section{INTISARI}

Tujuan penelitian adalah mengukur pengaruh persepsi terhadap atribut produk pada sikap terhadap produk dan pengaruh sikap terhadap produk pada niat pembelian dan menganalisis peran sikap terhadap produk sebagai variabel mediasi pada hubungan persepsi terhadap atribut pada niat pembelian ulang. Objek penelitian yang digunakan adalah produk daging olahan beku. Penelitian yang dilakukan dengan survei melibatkan 100 ibu rumah tangga responden yang ditentukan dengan metode pengambilan sampel yang didasarkan pertimbangan peneliti mampu memberikan informasi, dengan kriteria responden adalah pengambil keputusan pembelian bahan pangan keluarga. Analisis data dilakukan dengan analisis regresi linier sederhana dan berganda. Hasil penelitian menunjukkan bahwa persepsi terhadap atribut berpengaruh positif pada sikap terhadap produk dan selanjutnya sikap terhadap produk berpengaruh pada niat pembelian ulang produk. Kemampuan persepsi terhadap atribut produk dalam menjelaskan sikap konsumen adalah $36,5 \%$ sedangkan kemampuan sikap konsumen dalam menjelaskan niat pembelian ulang adalah $61,6 \%$. Uji mediasi menunjukkan bahwa sikap memediasi penuh hubungan persepsi terhadap atribut pada niat pembelian ulang.

(Kata kunci: Persepsi terhadap atribut produk, Sikap, Niat pembelian ulang)

\begin{abstract}
The objectives of the study were to measure the influence of product attribute perception to attitude toward product, the effect of attitude toward product to repeat purchase intention and to confirm that attitude toward product is a mediating variable between effect in relationship of product attribute perception to repeat purchase intention. One hundred (100) housewives determined by judgmental sampling method were used in the study. The criterion of respondent selected was that he/she has a role as food buying decision maker. Data were analyzed by simple and multiple regression analysis. The results indicated that perception on product attribute had significant effect on attitudes toward product and attitude toward product influenced repeat purchase intention. The study showed that $36.5 \%$ attitude toward product can be explained by consumer product attribute perception, while 61.6\% repeat purchase intention can be explained by attitude toward product. Study also confirmed that attitude toward product attribute was a fully mediating variable relationship of attitude and purchase intention.
\end{abstract}

(Key words: Perception, Attitude, Repeat purchase intention)

\section{Pendahuluan}

Kemajuan teknologi, meningkatnya pendapatan dan tingkat pendidikan konsumen meningkatnya proporsi protein hewani dalam konsumsi (Khotimah, 2001). Aspek kepraktisan tanpa mengurangi nilai gizi mulai menjadi pertimbangan terutama pada masyarakat kelas menengah dan atas, hal ini menunjukkan adanya kecenderungan pembelian bahan pangan "ready to cook" atau "ready to eat" (Khotimah, 2001). Daging sebagai bahan yang

\footnotetext{
* Korespondensi (corresponding author):

Telp.+62815687 8525, E-mail: ssyahlani@yahoo.com
}

mempunyai nilai nutrisi tinggi mengandung asam amino esensial yang lengkap dan seimbang (Soeparno, 1992) memiliki komposisi kimia air 65-80\%, protein $16-22 \%$, substansi-substansi non protein yang larut 3,5\%, lemak 3\% 1,5-13\% (Lawrie, 2003). Berbagai keunggulan tersebut menjadikan daging bersifat mudah rusak karena menjadikan daging sebagai media yang baik bagi pertumbuhan mikroorganisme. Pengolahan daging segar menjadi produk olahan beku merupakan proses yang sangat penting (Astawan, 2004) yang berfungsi untuk memperpanjang masa simpan terutama dengan teknik pembekuan (Lampila dan Lahteenmaki, 2007), penganekaragaman bahan pangan memberikan nilai 
tambah daging segar (Ikrawan, 2004). Teknologi pengolahan menjamin produk "ready to cook" tetap memiliki kandungan nilai gizi tinggi dan cita rasa bahkan pada beberapa produk diperkaya dengan kandungan gizi yang tidak ditemui pada bahan baku segar.

Berbagai produk olahan beku baik siap olah atau santap seperti chicken nugget, baso, pizza, spaghetti, karagee, strips, dan pok pok saat ini mudah dijumpai di pasar modern maupun pasar tradisional. Proses memasak bahan pangan tersebut dapat dilakukan dengan peralatan memasak yang praktis, tidak membutuhkan tempat luas dan dapat diolah dalam waktu yang singkat (Ikrawan, 2004). Berbagai kelebihan tersebut menjadikan produk daging olahan beku mendapat respon baik dari konsumen yang terlihat dari perkembangan peluang pasar yang baik di Indonesia. Produk daging olahan beku dipasarkan dalam berbagai merek dagang, kemasan, cita rasa, tekstur, dan harga jual yang terkemas dalam suatu atribut produk.

Berbagai atribut yang terkandung dalam produk olahan tersebut sama halnya dengan produk dan jasa lain yang dijelaskan Tjiptono (1997), merupakan unsur produk yang dipandang penting oleh konsumen dan dijadikan sebagai pertimbangan dalam pengambilan keputusan pembelian. Proses ini konsumen melakukan evaluasi kesesuaian produk dengan keinginan dan kebutuhan konsumen. Atribut produk diharapkan berfungsi untuk memberikan informasi kepada konsumen untuk menentukan pilihan, hal ini menjadikan atribut produk merupakan faktor yang harus dikelola dengan baik agar pelanggan dapat mengetahui dengan pasti manfaat yang terkandung dalam suatu produk (Rangkuti, 2004). Keunikan suatu produk dapat dijelaskan melalui pemakaian atribut yang menunjukkan perbedaannya dengan produk sejenis diantaranya melalui merek, harga, kemasan, atau informasi komposisi.

Chernev (2004) menjelaskan bahwa adanya kesesuaian antara proses evaluasi melalui identifikasi dan penilaian atribut produk dengan pilihan konsumen. Konsumen dalam menentukan pilihan produk akan menilai serta membandingkan berbagai macam produk berdasarkan konsistensi manfaat dan kualitas produk. Keunggulan kompetitif suatu atribut produk merupakan karakteristik dominan seperti warna, rasa dan fitur produk yang akan dapat memenuhi selera konsumen. Pengetahuan, pengalaman dan kepercayaan yang terintepretasikan melalui atribut produk tersebut akan mendorong konsumen untuk melakukan keputusan pembelian ulang di masa yang akan datang (Peter dan Olson, 2002). Penelitian yang dilakukan Darmawan dan Ferrinadewi (2004) menghasilkan hasil yang konsisten yaitu proses pengambilan keputusan pembelian diindikasikan oleh banyaknya atribut yang digunakan konsumen untuk membandingkan antara produk satu dengan yang lainnya.

Hubungan evaluasi atribut produk pada keputusan beli melibatkan variabel sikap. Berg et al. (2000) dan Rah et al. (2004) dalam penelitiannya menyatakan bahwa terdapat pengaruh yang signifikan antara variabel sikap terhadap niat beli. Temuan Tudoran et al. (2009) juga menjelaskan bahwa persepsi berpengaruh positif dalam membentuk niat, lebih lanjut dijelaskan bahwa persepsi memediasi sikap dalam menentukan keputusan pembelian. Crosby dan Taylor (1983) cit. Dharmmesta (2003) yang menyatakan bahwa sikap memiliki peran dalam mengarahkan keyakinan untuk membentuk suatu niat melakukan sesuatu.

Uraian tersebut menunjukkan pentingnya dilakukan kajian pengambilan keputusan belanja pada produk daging olahan beku yang secara spesifik bertujuan untuk mengukur pengaruh persepsi terhadap atribut produk pada sikap terhadap produk dan pengaruh sikap terhadap produk pada niat pembelian dan menganalisis peran sikap terhadap produk sebagai variabel mediasi pada hubungan persepsi terhadap atribut pada niat pembelian ulang. Pilihan kategori produk daging olahan beku dilakukan mengingat sejauh ini belum pernah dilakukan penelitian serupa pada kategori produk daging olahan beku yang secara kontekstual juga merupakan bagian dari industri peternakan yang berkembang pesat di Indonesia.

\section{Pengembangan model dan hipotesis}

Persaingan produk yang semakin ketat di pasar menuntut produsen untuk terus melakukan inovasi produk agar dapat selalu memberikan daya tarik produk kepada konsumen. Kehadiran produk pangan beku telah menjadi fokus perhatian konsumen di beberapa negara maju seperti Jepang dan

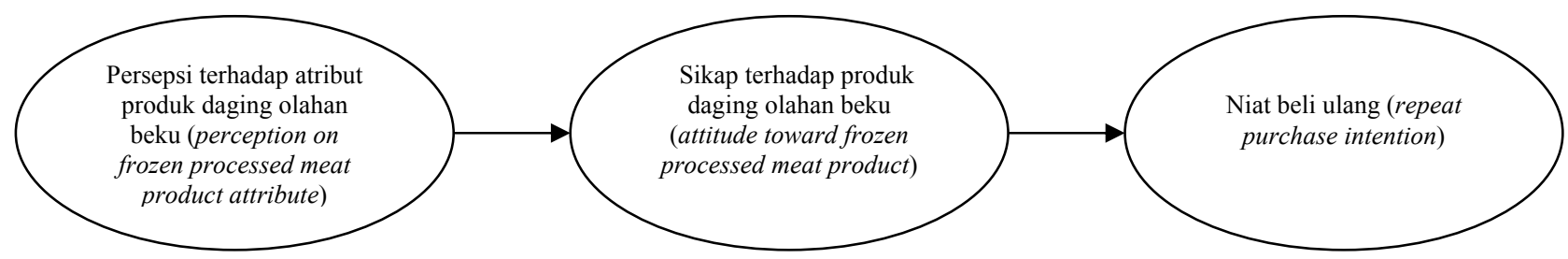

Gambar 1. Model penelitian (research model) 
Amerika serta diyakini sebagai salah satu inovasi produk yang merupakan kunci sukses di masa depan (Lampila dan Lahteenmaki, 2007). Produsen harus memahami nilai-nilai produk yang dianggap penting oleh konsumen dan menonjolkannya melalui kombinasi atribut produk meliputi kualitas produk, rancangan produk dan ciri produk yang secara psikologis dapat memberikan kesan positif (Kotler dan Armstrong, 2004). Penentuan atribut produk melalui inovasi rancangan produk, fitur produk maupun peningkatan kualitas produk juga akan mempermudah produsen dalam memposisikan produknya di pasar sehingga hal ini digunakan dalam konsep pemasaran produk (Kotler dan Keller, 2009).

Atribut produk merupakan faktor penting dalam proses pengambilan keputusan pembelian. Rao (1996) menjelaskan terbentuknya persepsi konsumen terhadap suatu barang atau jasa salah satunya adalah melalui pendekatan evaluasi atribut produk barang atau jasa tersebut. Melalui atribut produk, konsumen mendapatkan informasi kinerja produk untuk dapat memenuhi harapannya. Konsumen secara kognitif akan melakukan penilaian perasaan puasnya dengan membandingkan perbedaan antara kumpulan atau kombinasi atribut produk yang dipandang ideal oleh konsumen dengan persepsi kombinasi atribut yang sebenarnya. Identifikasi dan evaluasi terhadap atribut produk tersebut selanjutnya menjadi bahan pertimbangan konsumen untuk memilih produk yang dikehendaki.

Persepsi konsumen yang baik terhadap atribut suatu produk akan menimbulkan sikap suka terhadap produk tersebut yang selanjutnya mendorong konsumen untuk melakukan pembelian ulang (Kotler dan Armstrong, 2004). Temuan hasil studi Chernev (2004) menunjukkan bahwa adanya kesesuaian antara proses evaluasi melalui identifikasi dan penilaian atribut produk dengan tujuan pilihan konsumen. Temuan ini sejalan dengan penelitian Darmawan dan Ferrinadewi (2004), yang menyatakan bahwa konsumen cenderung untuk mempertimbangkan atribut produk dalam rangka mengurangi resiko yang mungkin dihadapin. Grolleau dan Caswell (2005) menyatakan bahwa konsumen memperoleh manfaat dari mengkonsumsi produk pangan yang dibeli melalui proses penilaian atribut produk sehingga atribut menjadi penting dalam sebuah produk. Berdasarkan uraian tersebut dapat dikembangkan hipotesis sebagai berikut :

$\mathrm{H}_{1}=$ Persepsi terhadap atribut produk berpengaruh positif pada sikap terhadap produk daging olahan beku.

Dharmmesta (2003) menjelaskan bahwa sikap merupakan suatu kecenderungan individu untuk berperilaku secara konsisten terhadap objek yang dimaksud. Hal ini dikarenakan konsumen memiliki kecenderungan untuk memilih produk yang disukai dan dirasakan dapat memberikan nilai lebih di antara produk sejenisnya, seperti memilih produk yang sesuai dengan selera, praktis dan inovatif. Sikap juga memiliki peran dalam mengarahkan keyakinan untuk membentuk niat melakukan sesuatu. Penilaian terhadap atribut produk yang baik dan sikap positif pada pembelian sebelumnya akan sangat berpengaruh terhadap keputusan konsumen untuk melakukan pembelian pada masa yang akan datang. Berg et al. (2000) menyatakan bahwa adanya pengaruh yang signifikan antara variabel sikap terhadap niat beli. Uraian tersebut mengarahkan pada hipotesis sebagai berikut :

$\mathrm{H}_{2}=$ Sikap terhadap produk berpengaruh positif pada niat beli ulang produk daging olahan.

Peran sikap sebagai variabel pemediasi pada pengaruh persepsi pada perilaku ditemukan tidak konsisten dalam berbagai penelitian. Sebelum pembelian dilakukan oleh konsumen, yang pertama tercipta adalah persepsi konsumen terhadap produk atau merek kemudian diikuti yang kemudian mempengaruhi sikap (Alpert dan Kamins, 1995). Penelitian Tudoran et al. (2009) menyatakan bahwa persepsi memiliki peran langsung dalam menentukan perilaku dan merupakan pemediasi antara pengaruh sikap dan niat beli. Berg et al. (2000) dan Rah et al. (2004) menyatakan bahwa sikap berpengaruh positif dalam membentuk niat. Individu cenderung memiliki sikap yang searah dengan perilaku. Berdasarkan uraian tersebut dikembangkan hipotesis sebagai berikut :

$\mathrm{H}_{3}=$ Sikap terhadap produk merupakan variabel mediator pengaruh persepsi terhadap atribut produk pada niat beli ulang produk daging olahan.

\section{Materi dan Metode}

Penelitian dilakukan dengan desain survei pada 100 responden yang ditentukan dengan judgment sampling method yang merupakan metode pengambilan sampel didasarkan pada penilaian peneliti responden mampu memberikan informasi yang relevan (Sekaran, 2006). Kategori produk yang digunakan dalam penelitian adalah produk daging olahan. Terkait dengan kategori produk yang digunakan dalam penelitian, maka ditentukan kriteria penentuan responden adalah ibu rumah tangga yang yang pernah melakukan pembelian produk daging olahan, memiliki informasi tentang produk daging olahan, memiliki kemampuan secara sosial ekonomi dalam melakukan pembelian dan penyimpanan produk daging olahan serta memiliki akses yang cukup mudah untuk mencapai tempat 
penjualan produk daging olahan. Penggunaan ibu rumah tangga sebagai responden dilakukan dengan pertimbangan bahwa peran seorang ibu rumah tangga dalam suatu keluarga dominan dalam melakukan keputusan pembelian pangan (Syahlani, 2006).

Instrumen penelitian yang digunakan dalam penelitian adalah kuesioner yang mengukur persepsi terhadap atribut produk daging olahan, sikap terhadap produk daging olahan dan niat beli ulang produk daging olahan. Skala yang digunakan adalah skala Likert. Pengumpulan data dilakukan dengan memberikan kuesioner kepada responden yang ditemui peneliti secara langsung, karena metode menurut Sarwono (2006) dapat meningkatkan akurasi perolehan data.

Data yang terkumpul dilakukan terlebih dahulu uji kualitas data meliputi uji validitas dan reliabilitas. Uji validitas yang dilakukan adalah adalah validitas konstruk untuk memperoleh keyakinan bahwa derajat skor pengukuran bahwa skor antara variabel satu dengan variabel lain yang didesain tidak berkorelasi (Sekaran, 2006). Selanjutnya dilakukan uji reliabilitas untuk mengukur konsistensi item penyusun instrumen penelitian dengan menggunakan metode Cronbach's alpha. Konsistensi antar-item hasil analisis reliabilitas diindikasikan dari nilai corrected item-total correlation yang dapat dinyatakan konsisten apabila nilai $\mathrm{r}$ lebih besar dari $r$ tabel yaitu 0,30 (Sugiyono, 1999). Analisis data yang untuk menguji hipotesis adalah analisis regresi linier sederhana dan berganda untuk pengujian hipotesis. Analisis tersebut dimungkinkan pada data yang dihasilkan dari kuesioner dengan skala Likert karena data yang dihasilkan memiliki klasifikasi, urutan dan jarak sehingga dapat dikategorikan data interval (Cooper dan Schindler, 2006). Data yang digunakan merupakan rerata dari penjumlahan skor yang diperoleh dari semua item pengukuran variabel yang dimungkinkan karena variabel yang digunakan dalam penelitian ini adalah unidimensional (Aaker et al., 2007).

\section{Hasil dan Pembahasan}

\section{Uji kualitas data}

Uji validitas yang dilakukan dengan product moment correlation menunjukkan hasil yang tercantum pada Tabel 1. Hasil uji tersebut menunjukkan adanya korelasi yang signifikan antar variabel penelitian namun nilai tersebut lebih kecil dari nilai 0,80 sehingga menunjukkan tidak akan memberikan efek mengganggu pada uji statistik yang akan dilakukan selanjutnya (Cooper dan Schindler, 2006).

Hasil uji reliabilitas menunjukkan bahwa dari 17 butir pertanyaan terdapat 1 butir pada pengukuran niat beli ulang dinyatakan gugur sehingga tidak digunakan dalam analisis. Selanjutnya dilakukan uji

Tabel 1. Hasil uji validitas variabel penelitian (validity test of research variable)

\begin{tabular}{|c|c|c|c|}
\hline Variabel (variable) & $\begin{array}{l}\text { Persepsi terhadap atribut } \\
\text { produk daging olahan beku } \\
\text { (perception on frozen } \\
\text { processed meat product } \\
\text { attribute) }\end{array}$ & $\begin{array}{l}\text { Sikap terhadap produk } \\
\text { daging olahan beku } \\
\text { (attitude toward frozen } \\
\text { processed meat } \\
\text { product) }\end{array}$ & $\begin{array}{l}\text { Niat beli ulang } \\
\text { (repeat purchase } \\
\text { intention) }\end{array}$ \\
\hline $\begin{array}{l}\text { Persepsi terhadap atribut produk daging } \\
\text { olahan beku (perception on frozen } \\
\text { processed meat product attribute) }\end{array}$ & 1,000 & $0,604 *$ & $0,535^{*}$ \\
\hline $\begin{array}{l}\text { Sikap terhadap produk } \\
\text { daging olahan beku (attitude toward } \\
\text { frozen processed meat product) }\end{array}$ & $0,604 *$ & 1,000 & $0,785^{*}$ \\
\hline $\begin{array}{l}\text { Niat beli ulang (repeat purchase } \\
\text { intention) }\end{array}$ & $0,535^{*}$ & $0,785^{*}$ & 1,000 \\
\hline
\end{tabular}

* Signifikan $(\mathrm{p} \leq 0,01)($ significant $(p \leq 0.01))$.

Tabel 2. Reliabilitas variabel penelitian (reliability test of research variable)

\begin{tabular}{lcc}
\hline \hline \multicolumn{1}{c}{ Variabel (variable) } & $\begin{array}{c}\text { Jumlah butir pertanyaan } \\
\text { (no of items) }\end{array}$ & $\begin{array}{c}\text { Cronbach's } \\
\alpha\end{array}$ \\
\hline $\begin{array}{l}\text { Persepsi terhadap atribut produk daging olahan beku (perception on } \\
\text { frozen processed meat product attribute) }\end{array}$ & 9 & 0,872 \\
$\begin{array}{l}\text { Sikap terhadap produk daging olahan beku (attitude toward frozen } \\
\text { processed meat product) }\end{array}$ & 5 & 0,883 \\
Niat beli ulang (repeat purchase intention) & 2 & 0,896 \\
\hline
\end{tabular}


reliabilitas dengan menggunakan 16 butir pertanyaan dan dihasilkan nilai Cronbach's alpha yang tercantum pada Tabel 2. Hasil pengujian reliabilitas menunjukkan angka di atas 0,6 dan mendekati angka 1,0 sehingga keandalan konsistensi internal dapat diterima.

\section{Pengaruh persepsi terhadap atribut produk daging olahan pada sikap terhadap produk daging olahan}

Tabel 3 menunjukkan bahwa $\mathrm{H}_{1}$ terdukung sehingga persepsi terhadap atribut produk berpengaruh secara signifikan pada sikap terhadap produk daging olahan pada $\mathrm{p} \leq 0,05$. Koefisien regresi untuk persepsi terhadap atribut produk pada sikap terhadap produk daging olahan adalah sebesar 0,604 . Nilai positif pada koefisien regresi menunjukkan bahwa semakin besar persepsi konsumen terhadap atribut produk maka akan semakin tinggi perannya dalam pembentukan sikap terhadap produk daging olahan. Persepsi responden penelitian terhadap atribut produk daging olahan yang meliputi kualitas produk, rancangan produk dan fitur produk dapat menimbulkan rangsangan pada sikap konsumen terhadap produk daging olahan tersebut. Persepsi terbentuk dari serangkaian informasi dan atribut intrinsik diantaranya warna, ukuran, fitur dan lain-lain. Kotler dan Armstrong (2004) menjelaskan bahwa dorongan seseorang dalam melakukan sebuah tindakan dipengaruhi oleh persepsi terhadap situasi disekitarnya dengan melakukan proses seleksi dan evaluasi atas semua informasi dan stimuli yang ada dirasakan melalui panca indera. Atribut produk bahan pangan sedapat mungkin mencerminkan keunggulan produk meliputi keamanan pangan, nutrisi, dan komposisi produk sehingga dapat merangsang sikap positif konsumen terhadap produk (Noelke et al., 2004 cit. Grolleau dan Caswell, 2005). Beberapa penelitian lain men- jelaskan bahwa beberapa faktor yang berperan dalam pemilihan produk pangan adalah persepsi dan sikap terhadap atribut produk (Verbeke, 2000) dan harapan kualitas sesungguhnya yang diperoleh sebelum dan setelah pembelian dan konsumsi (Grunert, 2002). Nilai $R^{2}$ menunjukkan kemampuan persepsi atas atribut produk dalam menjelaskan sikap atas produk daging olahan adalah sebesar $36,5 \%$, sedangkan sisanya sebesar $63,5 \%$ dipengaruhi faktor lain yang tidak diamati dalam penelitian.

\section{Pengaruh sikap terhadap produk pada niat beli ulang produk daging olahan}

Hasil analisis menunjukkan bahwa $\mathrm{H}_{2}$ terdukung sehingga sikap terhadap produk berpengaruh secara signifikan pada niat beli ulang produk daging olahan pada $p \leq 0,05$. Koefisien regresi untuk sikap terhadap produk pada niat beli ulang produk daging olahan adalah sebesar 0,785 sehingga menunjukkan besarnya peran variabel sikap dalam mendorong niat beli ulang produk daging olahan. Nilai $\mathrm{R}^{2}$ yang diperoleh 0,616 sehingga $61,6 \%$ niat beli ulang produk daging olahan dipengaruhi oleh sikap konsumen terhadap produk, sedangkan sisanya sebesar 38,4\% dipengaruhi oleh faktor-faktor lain yang tidak diamati dalam penelitian.

Temuan penelitian selaras dengan penelitian Rah et al. (2004) yang mengemukakan bahwa adanya pengaruh yang signifikan variabel sikap terhadap niat membeli ulang. Sikap mengarahkan individu dalam membentuk niat untuk membeli suatu produk. Sikap merupakan faktor penting dalam pengambilan keputusan pembelian. Dharmmesta (1998) cit. Istiana (2008) menjelaskan bahwa sikap konsumen dapat menjadi kontrol yang akurat terhadap perilaku pembelian. Semakin baik sikap dan norma subyektif terhadap suatu perilaku beli,

Tabel 3. Uji regresi linier pengaruh variabel persepsi, sikap dan niat beli ulang produk daging olahan beku (linear regression analysis on influence of perception, attitude and repeat purchase intention of frozen processed meat product)

\begin{tabular}{llcccc}
\hline \hline \multicolumn{1}{c}{$\begin{array}{c}\text { Variabel bebas (independent } \\
\text { variable) }\end{array}$} & $\begin{array}{c}\text { Variabel terikat (dependent } \\
\text { variable) }\end{array}$ & $\mathrm{N}$ & $\begin{array}{c}\mathrm{R} \\
\text { square }\end{array}$ & $\begin{array}{c}\text { Koefisien } \\
\text { (coefficient) }\end{array}$ & $\begin{array}{c}\text { Signifikansi } \\
\text { (significance) }\end{array}$ \\
\hline $\begin{array}{l}\text { Persepsi terhadap atribut produk } \\
\text { daging olahan beku (perception } \\
\text { on frozen processed meat product } \\
\text { attribute) }\end{array}$ & $\begin{array}{l}\text { Sikap terhadap produk daging } \\
\text { olahan beku (attitude toward } \\
\text { frozen processed meat product) }\end{array}$ & 100 & 0,365 & 0,604 & 0,000 \\
$\begin{array}{l}\text { Sikap terhadap produk daging } \\
\text { olahan beku (attitude toward } \\
\text { frozen processed meat product) }\end{array}$ & $\begin{array}{l}\text { Niat beli ulang (repeat } \\
\text { purchase intention) }\end{array}$ & 100 & 0,616 & 0,785 & 0,000 \\
$\begin{array}{l}\text { Persepsi terhadap atribut produk } \\
\text { daging olahan beku (perception } \\
\text { on frozen processed meat product } \\
\text { attribute) }\end{array}$ & $\begin{array}{l}\text { Niat beli ulang (repeat } \\
\text { purchase intention) }\end{array}$ & 100 & 0,287 & 0,535 & 0,000 \\
\hline
\end{tabular}


Tabel 4. Uji regresi hubungan mediasi (linear regression analysis of mediating effect attitude toward frozen processed meat product)

\begin{tabular}{|c|c|c|c|c|}
\hline $\begin{array}{l}\text { Pengujian } \\
\text { (analysis) }\end{array}$ & Variabel bebas (independent variable) & Variabel terikat (dependent variable) & $t_{\text {hitung }}$ & $\begin{array}{l}\text { Signifikansi } \\
\text { (significance) }\end{array}$ \\
\hline I & $\begin{array}{l}\text { Persepsi terhadap atribut produk daging } \\
\text { olahan beku (perception on frozen } \\
\text { processed meat product attribute) }\end{array}$ & $\begin{array}{l}\text { Sikap terhadap produk daging olahan } \\
\text { beku (attitude toward frozen } \\
\text { processed meat product) }\end{array}$ & 7,503 & 0,000 \\
\hline II & $\begin{array}{l}\text { Sikap terhadap produk daging olahan } \\
\text { beku (attitude toward frozen processed } \\
\text { meat product) }\end{array}$ & $\begin{array}{l}\text { Niat beli ulang (repeat purchase } \\
\text { intention) }\end{array}$ & 12,545 & 0,000 \\
\hline III & $\begin{array}{l}\text { Persepsi terhadap atribut produk daging } \\
\text { olahan beku (perception on frozen } \\
\text { processed meat product attribute) }\end{array}$ & $\begin{array}{l}\text { Niat beli ulang (repeat purchase } \\
\text { intention) }\end{array}$ & 6,276 & 0,000 \\
\hline \multirow[t]{2}{*}{ IV } & $\begin{array}{l}\text { Persepsi terhadap atribut produk daging } \\
\text { olahan beku (perception on frozen } \\
\text { processed meat product attribute) }\end{array}$ & $\begin{array}{l}\text { Niat beli ulang (repeat purchase } \\
\text { intention) }\end{array}$ & 1,232 & 0,221 \\
\hline & $\begin{array}{l}\text { Sikap terhadap produk daging olahan } \\
\text { beku (attitude toward frozen processed } \\
\text { meat product) }\end{array}$ & & 0,928 & 0,000 \\
\hline
\end{tabular}

maka pengaruhnya terhadap niat konsumen semakin kuat untuk melaksanakan perilaku pembelian yang dimaksud. Sikap berfungsi mengarahkan perilaku untuk mendapatkan penguatan positif, karena itu sikap berperan sebagai operant conditioning. Manfaat dari produk bagi konsumen yang menyebabkan seseorang menyukai produk tersebut. Pengetahuan tentang manfaat produk penting bagi konsumen karena pengetahuan akan mempengaruhi keputusan pembeliannya.

\section{Peran sikap sebagai variabel mediasi persepsi pada niat beli ulang produk daging olahan}

Tabel 4 menunjukkan bahwa sikap merupakan variabel yang memediasi sempurna pengaruh persepsi pada niat beli ulang. Pengujian persepsi dan sikap sebagai variabel independen secara bersama pada niat beli ulang meniadakan pengaruh persepsi pada niat beli ulang, sedangkan nilai signifikansi pengaruh sikap terhadap produk pada niat beli ulang adalah signifikan pada $p \leq 0,05$. Hasil penelitian menjelaskan bahwa mediasi yang terjadi adalah mediasi sempurna karena pengaruh persepsi terhadap atribut produk pada niat beli ulang tidak terlihat lagi ketika variabel mediator yaitu sikap terhadap produk dikontrol. Artinya bahwa persepsi atas atribut tidak berpengaruh lagi terhadap niat beli ulang produk daging olahan dan hanya variabel sikap atas produk yang berpengaruh terhadap niat beli ulang. Pernyataan tersebut di atas membuktikan bahwa sikap terhadap produk memediasi hubungan antara persepsi terhadap atribut produk dan niat beli ulang produk daging olahan. Hasil penelitian sejalan dengan penelitian Crosby dan Taylor (1983) cit. Dharmmesta (2003) yang menyatakan bahwa sikap termasuk dalam dimensi afektif yang memainkan peran dalam mengarahkan keyakinan untuk membentuk suatu niat atau komitmen melakukan sesuatu. Lebih lanjut dijelaskan Dharmmesta (2003) bahwa seseorang cenderung membawa sikapnya searah dengan perilaku. Sikap yang terbentuk secara keperilakuan akan mengarah pada pertalian antara objek dan evaluasi yang lebih kuat sehingga akan lebih mudah diakses dari memori.

\section{Kesimpulan}

Hasil penelitian menunjukkan konsistensi bahwa persepsi terhadap atribut produk mempengaruhi sikap terhadap produk dan sikap terhadap produk mendorong niat konsumen untuk melakukan pembelian ulang. Hasil penelitian juga menunjukkan bahwa sikap merupakan variabel yang berperan sebagai pemediasi penuh pengaruh persepsi konsumen terhadap atribut produk pada niat pembelian ulang.

\section{Daftar Pustaka}

Aaker, D.A., V. Kumar, and G.S. Day, 2007. Marketing Research. John Wiley and Sons, Inc., New Jersey.

Alpert, F.H. and M.A. Kamins. 1995. An empirical investigation of consumer memory, attitude, and perceptions toward pioneer and follower brands. Journal of Marketing 59:34-45.

Astawan, M., 2004. Mengapa kita perlu makan daging. Available at http//www.keluarga sehat.com. Accession date: 30 Maret 2008.

Baron, R.M. and D.A. Kenny. 1986. The moderator-mediator variable distinction in social psychological research: conceptual, strategic, and statistic consideration. Journal 
of Personality and Social Psychology. 51(6): 1173-1182.

Berg, C., I. Jonsson, and M. Conner. 2000. Understanding choice of milk and bread for breakfast among Swedish children aged 1115 years: An Application of the Theory of Planned Behavior. Appetite 34:5-19.

Chernev, A. 2004. Goal attributes compability in consumer choice. Journal of Consumer Psychology. Kellogg Scholl of Management Northwestern University. Lawrence Elrbaum Associates, Inc.

Cooper, D.R. and P.S. Schindler. 2006. Business Research Methods. $9^{\text {th }}$ ed. McGraw - Hill. International Edition.

Darmawan, D. dan E. Ferrinadewi. 2004. Perilaku Konsumen: Analisis Model Keputusan. Atmajaya. Yogyakarta.

Dharmmesta, B.S. 2003. Sikap dan Perilaku Konsumen Dalam Pemasaran: Sebuah Tinjauan Sosial-Kognitif. Kajian Bisnis. STIE Widya Wiwaha. Yogyakarta.

Grolleau, G. and J.A. Caswell. 2005. Interaction between food attributes in markets: The case of environmental labeling. Working Paper No. 2005-5. Department of Resources Economics. University of Masschusetts Amherst.

Grunert, K.G. 2002. Current issues in the understanding of consumer food choice. Trends in Food Science \& Technology 13(8): 275-285.

Ikrawan, Y. 2004. Menangani bahan beku. Available at http//www.pikiran-rakyat.com/ infopenelitian.htm. Accession date: 23 Maret 2008.

Istiana, L. dan S.P. Syahlani, 2008. Pengaruh sikap, norma subyektif dan kontrol keperilakuan terhadap niat dan perilaku pembelian susu ultra high temperature (UHT). Prosiding Pekan Promosi Susu Departemen Pertanian, Jakarta.

Khotimah, K. 2001. Studi tentang tingkat permintaan daging segar dan daging olahan (corned, sosis, dendeng) di supermarket Kodya Malang. Laporan Penelitian. Jurusan Produksi Ter-nak. Universitas Muhammadiyah. Malang.

Kotler, P. and K.L. Keller (2009), Marketing Management. $13^{\text {th }}$ ed. Upper Saddle River, N.J. : Pearson Education, Inc.
Kotler, P. and G. Armstrong. 2004. Principles of Marketing. $10^{\text {th }}$ ed. Pearson Prentice Hall.

Lampila, P. and L. Lahteenmaki. 2007. Consumer's attitudes towards high pressure freezing of food. British Journal Food. Emerald Group Publishing Limited.

Lawrie, R.A. 2003. Ilmu Daging. Edisi Kelima. UI Press. Jakarta.

Peter, J.P. and J.C. Olson. 2002. Consumer Behavior and Marketing Strategy. $6^{\text {th }}$ ed. International Edition. McGraw-Hill, New York.

Rangkuti, F. 2004. The Power of Brands. Cetakan II. Penerbit Gramedia Pustaka Utama. Jakarta.

Rah, J.H., Hasler, C.M., Painter, J.E. ChapmanNovakofski, K.M. 2004. Applying theory of planned behavior to women's behavioral attitudes on and consumption of soy products. Journal of Nutrition Education and Behavior 36(5):238-244.

Rao, P. 1996. Measuring Consumer Preception Through Factor Analysis. The Asian Manager, February-March, pp:28-32.

Sarwono, J. 2006. Analisis Data Penelitian Menggunakan SPSS. Penerbit Andi. Yogyakarta.

Sekaran, U. 2006. Research Methods for Business. Second Edition. Salemba Empat. Jakarta.

Syahlani, S.P. 2006. Efek informasi, sumber komunikasi pemasaran dan label pangan dalam proses adopsi: studi perilaku adopsi pangan fungsional. Disertasi. Program Pasca Sarjana. Universitas Gadjah Mada, Yogyakarta.

Soeparno. 1992. Ilmu dan Teknologi Daging. Gadjah Mada University Press. Yogyakarta.

Sugiyono. 1999. Metode Penelitian Bisnis. CV Alfabeta. Bandung.

Tjiptono, F. 1997. Strategi Pemasaran. Penerbit Andi. Yogyakarta.

Tudoran, A., S.O. Olsen, and D.C. Dopica. 2009. The effect of health benefit information on consumer health value, attitudes and intentions. Appetite 52(3):568-579.

Verbeke, W. 2000. Influences on the consumer decision-making process towards fresh meat: insight from belgium and implications. British Food Journal 102(7):522-538. 